\title{
A cultural turn in New Testament studies?
}

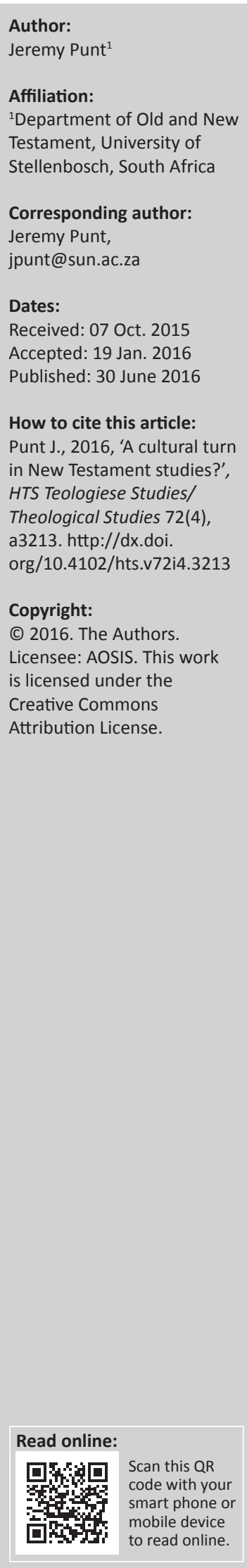

This article considers intersections between cultural studies and New Testament studies. It ponders and focuses on possible approaches to the bearing of the 'cultural turn' on biblical studies. Following a brief consideration of cultural studies and its potential value for New Testament studies, four promising developments in cultural studies approaches to the New Testament are noted.

\section{Introduction}

The late twentieth century's 'linguistic turn' marked the beginning of a new consciousness in hermeneutics and even epistemology in New Testament (NT) studies. ${ }^{1}$ This turn was related to a larger spectrum of changes sometimes referred to as 'culture wars' in the human and social sciences. ${ }^{2}$ These culture wars saw literary theorists' insistence on the discursive construction of reality, the elusiveness of truth, scientific scepticism and therefore, culture's independence of non-cultural forces clash with a social-scientific focus on materiality. The culture wars also caused the scientist to resolve to process physical elements in terms of (trans)disciplinary models. Both models left dumbfounded historical positivists ensconced in their particularistic approach to fragmentary evidence. The presence and impact of culture wars in biblical studies since the linguistic turn are still largely under-recognised and often unacknowledged. The linguistic turn did, of course, not lead in all instances to similar results, nor did it resonate equally among all scholars; it nevertheless (and at least) meant that the constitutive role and impact of language could no longer be denied. Traditional, long-held beliefs in historical objectivity and the ability to describe a past as it actually happened were increasingly replaced by the acknowledgement that the past does not exist outside of its literary presentation. ${ }^{3}$ And with the acknowledgement that the past exists only in its literary representation came the realisation that such representations are always imbued with ideology.

These and other culturally sensitive developments and ideas are increasingly, but only gradually, being absorbed into biblical studies practices. Some two decades ago it was suggested that the combination of rhetorical emphasis and feminist theory would enable the 'full-turn' of biblical studies, but a paradigm shift in biblical studies has so far largely remained elusive due to the inability of rhetoric to link up with feminist, liberationist and postcolonial studies (Schüssler Fiorenza 1999:13; cf Althaus-Reid 2002:398-400). Nevertheless, literary texts are increasingly being viewed as part of a larger 'inseparable, relational web of residues and artifacts that hang together in ways that are not always easily comprehensible' (Lopez 2011:80). The acknowledgement that such interconnectedness is also embedded in various power constellations has given rise to claims about a 'political turn' (Stanley 2011:111) in NT studies. ${ }^{4}$ However, a political turn has hardly become prominent and is certainly not characteristic of contemporary biblical studies.

Closely connected to what may be called lingering linguistic and incipient political turns, and also to a growing interest in cultural studies among NT scholars, references to a 'cultural turn' in NT studies are probably increasingly merited. ${ }^{5}$ For some the cultural turn may imply the employment of various poststructural hermeneutical approaches or even methods to show how language shaped the sociocultural setting of the early Christian world. For others it

1.Richard Rorty's edited volume of 1967 is sometimes cited as coining the term linguistic turn, but the linguistic turn's many precursors could include many others such as Ludwig Wittgenstein.

2.During (2005:18) refers to a different format of culture wars in the Anglophone West as comprising three warring factions, namely morality and censorship; commercial culture, and multiculturalism and migration (and perhaps a fourth, During adds, between Americanisation and its enemies)

3.'History itself, insofar as it is discernible by any human being, is just like a text in that it is constructed by a particular person in a particular time and place. And it must be interpreted like a text. There is, in the end, no escape from language and textuality' (Martin particular
2005:18).

4.The political and cultural turns at times move in opposite directions: see e.g. Harrill (2011).

5.For a brief discussion of how some scholars portray the cultural turn as growing out of the linguistic turn, and 'the centrality of textuality for the writing of history', see Martin $(2005: 7-9,18)$. 
entails the use of cultural anthropology as the analytical method for making sense of biblical texts. Regardless of the different understandings of cultural studies, what has nevertheless become clear is the movement of scholarly enquiry beyond the universalisms of the Enlightenment and nineteenth- and twentieth-century liberalism. The result is that, more and more, scholars have come to view human beings as historical creatures located within the complex matrices of particular cultures and social worlds', and they increasingly deal with the 'located, particular, pluralistic, and thoroughly historical nature of human existence, experience, and knowledge' (Davaney 2001:5). In fact, since the latter part of the twentieth century, social history has been replacing institutional or intellectual history (Martin 2005:4), ${ }^{6}$ and in biblical studies investigations are shifting towards the ways in which the socio-cultural settings of antiquity influenced rhetorical strategies found in the ancient texts.

\section{Cultural studies and biblical studies: What and why?}

The cultural studies label is used for a broad field of academic work and research, including areas which intersect with and have an impact on biblical studies. ${ }^{7}$ The originating moments and location of cultural studies are commonly disputed, yet broadly connected to movements as early as the 1950s to study popular or mass culture - 'the whole of cultural production' - by devoting attention to films, television, radio, newspapers, magazines and so on, as 'texts', 'discursive practices' or 'signifying practices' (Easthope 1994:176). ${ }^{8}$ Although '[c]ultural studies is a tendency across disciplines, rather than a discipline itself' (Miller 2001:1), in the past it was often variously described, for example, as:

the study of everyday or popular culture, which began to find a niche in academia in the 1960s; in Britain ... especially as it relates to social hierarchies, economic processes, political power, and identity formation; in North America ... especially as expressed in the electronic media, with tools drawn largely from literary criticism and communication studies. (Vanhoozer, Anderson \& Sleasman 2007:248)

However, describing cultural hermeneutics as 'approaches to interpretation in which the social and cultural location of the interpreter (e.g. feminist, African-American) serves as a principle of interpretation' (Vanhoozer et al. 2007:248) does not show sufficient self-awareness about the discrepancy it introduces. Interpretation, after all, is never devoid of social

\footnotetext{
6.In social history issues such as "class and status, family and household, slavery, patron-client structures, travel and communications, and the influence of economics and urban life on developments in early Christianity and late antiquity (Martin 2005:4) receive attention. See also Port (2015:108-113) for a discussion of people's history, history from below and microhistory that moves beyond socia structures and trends to focus on individual agency within lived complexity.

7.Miller (2001: 1) calls cultural studies 'magnetic' for the wide range of approaches included under its umbrella, a 'master-trope'. Cf Punt (2012) for some deliberations on cultural studies from the perspective of past and future biblical studies.

8.During emphasises that cultural objects comprise at the same time "'texts" (that is they have meaning) and events and experiences, produced out of and thrown back into, a social force field constituted unevenly by power flows, status hierarchies and opportunities for many kinds of transportation, identification and pleasure' (2005:6. cf Bonnell \& Hunt 1999:2-3). See Smith (2014) for a brief and useful overview of the cf Bonnell \& Hunt 1999:2-3). See Smith (2014) for a brief and useful overview of the
development of cultural studies through various phases; also Tanner (2001) development of
}

or cultural influence as it is in and of itself social and cultural, as much as interpretation is never aloof from interpreters and often not without consuming listeners. In fact, in both instances, even if in various ways, interpreters as well as listeners and readers of the interpretation are both connected to and constitutive of their social locations. ${ }^{9}$

This cultural situatedness of interpretation fills out the cultural turn that followed in the footsteps of the linguistic turn (Chaney 1994:2; Martin 2005:8). Whereas the cultural turn in biblical studies can be (and is) explained variously, the understanding of and emphasis on certain antecedents are also - unsurprisingly - likely to vary between social locations. In biblical studies it is, on the one hand, the impending demise of the once all-vanquishing historical critical approach that raises questions about the nature of historical work, ${ }^{10}$ repositions linguistic and textual concerns and attention for readers, and focuses on their interpretative communities and histories. ${ }^{11}$ On the other hand, the rise of a more socially attuned historiography and concern for the social location of scholars and scholarship beg the question about modes of historical consciousness in scholarship when the social embeddedness of biblical studies informs points of departure and frames of understanding. ${ }^{12}$

\section{What are culture and cultural analysis?}

Culture is notoriously difficult to define, but can be understood as 'a social construction and integrated system of beliefs and practices'. ${ }^{13}$ However, until the latter part of the nineteenth century and with the work of EB Turner in particular culture was capitalised, inevitably 'high culture', used in the singular and equated with civilisation and directly connected to Western Europe - ironically, with different European peoples ultimately claiming the same

9."'The people" are not just passive consumers of meaning, values, and practices devised by the powerful. They are the producers of culture on multiple levels, including through resistance to elites' (Davaney 2001:6).

10.In cultural studies, 'The goal of the historian becomes not the conscious or even unconscious intentions of the author, but the larger matrix of symbol systems provided by the author's society from which he must have drawn whatever provided by the author's society from which he must
resources he used to 'speak his mind' (Martin 2005:17).

11.A cultural studies approach acknowledges both the value and the authenticity of popular readings without necessarily assuming the legitimacy or condoning the effects of any particular reading. Popular readings can also be 'an uneven mix of insights, prejudices, contradictions, and images imposed by hegemonic discourse' (Glancy 1998:476) and not necessarily innovative and liberatory. However, scholarly readings serve a useful purpose in conjunction with popular readings, for example in addressing the needs of the poor (cf Rowland 1993:239, 241). Hayden White, who mooted the idea of history writing as a 'poetic' construction of its author, can be considered the 'patron saint' of the cultural tum that was just getting underway in the 1970s (Eley 1996:207).

12. Cultural studies does not seek to exclude, or to take scholarly terrain hostage as it 'seeks to integrate, in different ways, the historical, formalist, and sociocultural seeks to integrate, in different ways, the historical, formalist, and sociocultural questions and concerns of other paradigms'; but it does seek to do so 'on a
different key, with a situated and interested reader and interpreter always at its core' (Segovia 2000:30, 41). In general, as Chaney puts it, the cultural turn refers to 'how we as ordinary members of society routinely trade upon and begin to express our sense of meaning, value and significance in everyday experience' (Chaney 1994:2)

13.Or 'a multilayered network of relations or total way of life encompassing the myriad relations, institutions, and practices that define a historical period or specific geographical location or formative community or subgroups within larger fields' (Davaney 2001:5). Few will disagree that culture is one of the most slippery terms to define; however, 'the very popularity of the term may be due in large part to its universality, capaciousness, and malleability' (cf Martin 2005:7). Williams s. la European languages, but mainly because it has now come to be used for importan concepts in several distinct intellectual disciplines and in several distinct and incompatible systems of thought' (1983:86). 
prize. With the West as the epitome of culture, so-called high culture equalled refinement across a wide range: taste, manners, sentiments, judgement and morals. Conversely, other cultures or civilisations were largely ignored, until Turner employed 'culture' as a subject of science. His work was taken further by the modern cultural anthropology of Franz Boas, whose intellectual cultural relativism ${ }^{14}$ obliterated the idea that cultural differences could be hierarchically graded as inferior or superior. However, in the extreme, cultural relativism presupposed not equality as much as incommunicability. A softer version 'holds that there are bases for communication, comparison, and even evaluation across cultures, even if cross-cultural analysis requires great care to take account of indigenous perspectives and sophisticated modes of translocation and interpretation' (Cosgrove, Weiss \& Yeo 2005:2-3). ${ }^{15}$

Moving beyond class-oriented 'high culture' or even the structural, systematic 'anthropological culture' (cf Geertz 1973) of earlier times, culture today is deemed unstable, contested and inclusive of non-elites, popular culture and sub-cultures along with the behavioural values and characteristics that constitute groups as such (cf Harrill 2011:284). Culture is a group of people's entire 'way of life' (Martin 2005:6). As During (2005) puts it:

[c]ulture is not a thing or even a system: it's a set of transactions, processes, mutations, practices, technologies, institutions, out of which things and events (such as movies, poems or world wrestling bouts) are produced, to be experienced, lived out and given meaning and value to in different ways within the unsystematic network of differences and mutations from which they emerged to start with. (p. 6)

Culture is both universal to all societies and particular in each case (Martin 2005:8), and as way of life calls for a different, broader understanding of power in society than was the case in the past. ${ }^{16}$ It corresponds to the way in which culture has been both popularised (no longer about great men and great ideas) and broadened out (beyond ideas and texts). In discussions about cultural dynamics, the struggle for and the negotiation of power is often at issue, with power also broadened out in two particular ways. Firstly, 'power is never located solely in one segment of society - in one class, race, or gender - but is in continual circulation and is constantly being reconfigured'. Secondly, (and taking a cue from Foucault), 'power is not just a repressive mechanism that exerts itself

14. In the words of Boas (1887.589), "iitt is my opinion that the main object of ethnological collections should be the dissemination of the fact that civilization is
not something absolute, but that it is relative, and that our ideas and conceptions not something absolute, but that it is relative,

15.Cosgrove et al. (2005:4) distinguish between approaches that are either multicultural (based on the affirmation of cultural pluralism and valuing cultura diversity, multi-cultural is a descriptive term for culturally diverse settings), crosscultural (the movement from one culture to another, whether the movement is plotted spatially, temporally, or both) or intercultural (about dialogue, exchange and debate between cultures, inevitably involving cross-cultural movement).

16.It was in film studies in particular that the focus shifted from the classic realist or representational text with its notions of empirical truth and the autonomous subject in a meta-position, or 'the position of dominant specularity'. Renewed subject in a meta-position, or 'the position of dominant specularity'. Renewed emphasis was devoted to the "theorisation of the subject position', in terms of both the subject's identity and their sociallocation, leaning heavily on Althusser, Lacan and Kristeva in the formulation of these theories (Easthope 1994:177). It meant
that the understanding of subjects and objects, agency and power was in need of refinement. through constraint and limitation but that control is also exercised through the construction of new possibilities, roles, identities, and institutions' (Davaney 2001:6).

It is at this point where the Bible comes into play, as it has been part of many cultures around the world and involved in such power negotiations, even if its current presence and its interpreters' agency also indicate newness. ${ }^{17}$

\section{The Bible and cultural studies, and its newness}

Northrop Frye (1982; cf Kwok 2005:82) referred to the Bible as the 'great code' that underwrites Western civilisation. In many other parts of the world, too, the Bible is part of the prevailing cultural legacies (e.g. Brenner 2000:7-12; Sugirtharajah 2003:81):

The Bible ... 'simply swarms us'. Western culture and literature are saturated with its language and imageries. It has invaded colonies and has intruded into the political and social and cultural life of peoples who were not necessarily part of the biblical heritage ... The overwhelming presence of the Bible was the result of modernity (Sugirtharajah 2002:204).

Emphasising its cultural role, David Tracy (1981, 1987) referred to the Bible as a 'classic' text. As classic it bears a surplus and longevity of meaning, but it nevertheless resists definitive interpretation. In fact, as in the past, the Bible can also function as a means of 'interruption' in cultural processes, depending on its interpreters' or consuming audiences' openness to engage its notions of truth.

Given this socio-historical setting of the Bible in many parts of the globe, leaning towards cultural studies is both to be expected and new. On the one hand, the academic pursuit of cultural studies is an indication of the popularisation of culture, though not without some irony, of course. Displacing essentialist notions of culture as 'the deposit or accumulation of knowledge or meaning produced by elites, or as a body of beliefs and values shared by all members of a group such as a nation or religious community' opens up alternative engagements with culture. Rather than static deposit, culture is now understood as 'the dynamic and contentious process by which meaning, and with it, power is produced, circulated, and negotiated by all who reside within a particular cultural milieu' (Davaney 2001:5). ${ }^{18}$

On the other hand, cultural studies as a way of investigating the NT can be seen as a form of 'newness' also in the sense Homi Bhabha used the notion:

The borderline work of culture demands an encounter with 'newness' that is not part of the continuum of past and present. It creates a sense of the new as an insurgent act of cultural translation .... It renews the past, refiguring it as a contingent

17.According to Bonnell and Hunt (1999:10-11), "[t]he most important characteristic of cultural studies is that they depend on a range of explanatory paradigms and deal fundamentally with issues of domination, that is contestations of power', and 'causal explanation takes a back seat, if it has a seat at all, to the demystification and deconstruction of power'.

18.Cf also Brown (2001:41-55) on the shift beyond essences to 'pragmatic historicism' and a 'new ethnography'. 
'in-between' space, that innovates and interrupts the performance of the present (Bhabha 1994:10).

Taking culture seriously in itself demands a different perspective on the past and the future, a rethinking of attitudes and concepts. It goes beyond investigating a text's Sitz im Leben to illuminate the text and enhance its interpretation, and also beyond contextual approaches of interest in relating an ancient text to present-day contexts. The newness of cultural studies is situated not only in its hybridity, impurity, intermingling, the transformation resulting from novel and unforeseen combinations of human beings, cultures, ideas, and various media but also in the celebration of this all as culture. ${ }^{19}$ But what do such understandings of matters cultural and biblical and their interconnections hold for NT studies?

\section{Cultural studies: How? Looking into the cultural crystal ball}

To begin with, cultural studies include other voices in society in the interpretation of the Bible because it privileges a 'polyphonic hermeneutics' (Glancy 1998:461). ${ }^{20}$ NT cultural studies proceeds from the vantage point of seeing the text as 'construction' - that is, interpretation and meaning is the result of an interactive process between reader and text (Segovia 1995c:296; cf 1995a:28-31, 1995b:7-17) ${ }^{21}$ and readers and their interactions with texts are deemed worthy of investigation. Biblical texts are regarded as other contemporary social groups, as socially and culturally conditioned 'others', since texts are never disconnected from specific settings in time and social location. Secondly, readers are equally regarded as socially and culturally conditioned 'others' to the text and other readers. Readers are taken seriously not as unique or independent individuals but rather as members of distinct and identifiable social configurations within social locations. Thirdly, the interactions between texts and readers are not neutral encounters but filterings of the text through (the world of) the reader. ${ }^{22}$ Beyond the otherness of reader and text, the interaction between text and reader (reading) consists of construction as well as engagement. All attempts at reconstructing the text regardless of the rigours involved, and also (even) as the

19.It rejoices in mongrelization and fears the absolutism of the Pure. Mélange hotchpotch, a bit of this and bit of that is how newness enters the world' (Rushdie 1991:393, emphasis in the original).

20.Cf eg the essays in the volumes edited by Exum and Moore (1998) and Moore (1998). Although issuing caution for its being a tentative description, Segovia refers to his preference for the fourth option (besides historical criticism, literary criticism and cultural criticism) in contemporary biblical studies as cultural studies or and cultural criticism) in contemporary biblical studies as cultural studies or ideological criticism (Segovia 1998:35,
contributions that of Blount (1995).

21.The intentions and conscious thinking of authors do not disappear from view altogether, but no longer occupy the only or even the primary role in hermeneutics. In fact, the unspoken or unreflected assumptions or assumed meaning of authors needs to be placed in and filled out according to the prevailing culture. 'The goal of the historian becomes not the conscious or even unconscious intentions of the author but the larger matrix of symbol systems provided by the author's society from which he must have drawn whatever resources he used to "speak his mind" (Martin 2015:17).

22. Since conventional scholarship is rather reluctant to reflect upon its relationship with society generally (see Horsley 1995), the social engagement presupposed and required by postcolonial criticism, among other things, is at times considered ideologically laden and thus tainted, i.e. either irrelevant to, or a threat to, traditional and established approaches. 'other', are nothing else than construction. ${ }^{23}$ Engagement with the text, perceiving it as 'other' requires critical engagement with it towards an emancipatory goal; yet engagement with the text as 'other' requires effort to understand how the text was interpreted by others ${ }^{24}$ (Segovia 1995c:297-298).

It would be foolish to try to prescribe or predict the future twists of the cultural turn in NT studies. During (2005:6) says that it is not diffusion but mobility that characterises cultural studies today, crossing distances and borders and with changing social and material settings. In NT studies where cultural studies is also characterised by a diversity of (new) approaches and methodologies (cf Martin 2005:9 on late antiquity studies), four interesting and promising developments deserve mention, if only briefly. ${ }^{25}$

\section{Postcolonial work}

It is postcolonial theory as a particularly energetically pursued approach with important spin-offs within cultural studies that has, in recent years, consistently aided the interpretation of biblical texts. Postcolonial studies flowed from cultural studies, or became an aspect of new concern within cultural studies (Gallagher 1996:229), both of which sit uneasily with being conceptualised as another academic or scientific discipline in the traditional sense of the word. The value that postcolonial theory brings to biblical hermeneutics is found particularly in its role of accounting for the contexts of origin of biblical and related contemporary texts and documents. Going beyond traditional historicalcritical concerns, postcolonial work is particularly interested in the extent to which these texts and their interpretation were influenced by imperialist, socio-cultural, and economicpolitical powers - both past and present. More specifically to the discipline of theology, and to NT studies in particular, postcolonial theory offers valuable theoretical support for interpreting texts which originated in an imperial setting dominated by the Roman Empire and its collaborators.

The interpretation of biblical texts in the complex and often tension-filled situations and relationships between people and groups of people in the wake of the end of colonisation in Africa, and the fall of the South African apartheid regime - with the lingering effects and influences of these systems on the former colonies and 'new

23. As Wimbush argues, the 'cultural worlds of readers' determine which texts are to be read, how they are to be read, what they mean - even the meaning of 'text' be read, how they are to be read, what they mean - even the meaning of 'text'
itself (1993:129). Or as Harrill insists, 'The "cultural turn" emphasises the itself (1993:129). Or as Harrill insists, "The "cultural turn" emphasises the
inadequacy of reading texts to reconstruct the voices of ancient people, in favor of theorizing the discursive strategies in "texts" themselves' (2011:310).

24.Segovia's contributions on 'cultural studies' as an alternative interpretive paradigm for biblical studies are vital, and in particular his emphasis that text is more than means (as in historical criticism) or medium (as in literary criticism), or both (cultural criticism or socio-scientific criticism), since text also is construction (Segovia 2000:333).

25.Cf also Martin (2005:9), who sees the cultural turn as typefied by a diversity of new theoretical approaches, as it 'refers not to one particular theoretical or methodological innovation, but to a broad shift in textual and historical analyses of a newly defined field of study, analyses influenced, to be sure, by cultural anthropology and the social sciences, but more recently by a wide diversity of theories and methods borrowed from poststructuralism: various literary theories, theories and methods borrowed from poststructuralism: various literary theories,
discourse analysis, ideology critique, theories of the construction of the body and the self, feminist and gender studies, ritual studies'. Cf Carroll (1998:55-66). 
South Africa' - greatly benefits from postcolonial criticism. ${ }^{26}$ Given the ability of postcolonial theory to avoid strong and exclusivist binaries, through its focus on mimesis and hybridity in the postcolonial setting, theoretical perspectives become available with which to address pressing and lingering tensions but without the predisposed utopian tendency simply to reverse alienation, marginalisation and disenfranchisement. All too often this has led, in the postcolonial world, merely to a reversal of power while leaving structural and other unevenness intact. ${ }^{27}$

\section{Gender criticism and queer theory}

As a result of feminist theory and gender criticism moving more and more beyond social history and the 'recovery of woman' project since the 1980s and 1990s, a different analysis of and approach to gender emerged. More attention is devoted to the rhetorical construction of men and women, of femininity and masculinity, of gender in texts and discourse, as well as to investigations of the social forces at work in this regard. Going beyond essentialist approaches, cultural studies is interested in the involvement of body with language and textuality and the connection between reading and other forms of cultural interpretation (cf Martin 2005: 11-12). Gender is neither a fixed nor a natural category, one not determined ultimately by biological differences between men and women. But gender is culturally scripted: as a set of regulated practices it structures social hegemonies with regard to material bodies (Smith 2014).

Queer theory, generally believed to have been inspired by Michael Foucault and associated with the work of philosophers and sociologists such as Rubin, Sedgwick, Butler and Weeks, offers particularly valuable resources for cultural studies. A basic premise of queer theory is the denunciation that sexuality is a universal and eternal drive and the affirmation that sexuality is best viewed from a social constructionist position. ${ }^{28}$ Moving beyond the insideroutsider rhetoric so common in patriarchal identity and power, queer theory allows for a critical approach not only to social identity and location but also to social systems and institutions. In this sense, but also because queer theory destabilises the self-evidence of power and marginality,

26.Cultural studies and analysis and its value to work on the NT, and sustained investigations of the theoretical stance(s) with regard to postcolonial theory in particular, have much value in the post-apartheid South African context: a grounded position pointing to the significance of postcolonial hermeneutics in biblical interpretation, both for explaining texts in historical, imperial settings and also for understanding texts in South Africa, influenced by our global (post)modern and often neo-colonialist world. Cf Goss (1996:239-250) on postcolonial theory and activism.

27.In South Africa but also elsewhere, the academy in general and theology/biblical studies in particular increasingly become cognisant of and interact with contemporary contexts. Notwithstanding pockets of resistance, the tide is turning from detached, aloof scholarship to socially engaged academic work. Instead, socially engaged studies are only starting to establish some kind of a threshold for a more concerted effort to deal with contextuality effectively, responsibly and accountably. However, the remaining and still concerted drive away from contextuality should not be ignored or left unengaged.

28.'In a nutshell: what queer theory teaches us is that nothing is certain about sex and sexuality and that the social categories we have to organise, use and police it are contingent (they might be different and indeed are always in the process of becoming different). And the same is true, at the level of individuals and their bodies, for the pleasures and other intensities we take from sex, which although they may be offered to us as mediated through sex's social categories, are also they may be offered to us as mediated through sex's social categories, are also
open to modification by new ways of incorporating and acting out (or performing) gender as well as sexual drives' (During 2006:183-189). centre and periphery, it intersects with postcolonial studies (Punt 2011). ${ }^{29}$ In their focus on materiality, corporeality and sexuality, and the scripting of these in society with and through biblical texts, gender and queer studies in particular have become important heuristic approaches in biblical studies. ${ }^{30}$

\section{Beyond objectivism/subjectivism: Autobiographical hermeneutics}

Proponents of cultural studies make regular use of a wideranging spectrum of insights, borrowed from contemporary anthropology and ethnography in particular, which include economics, history, media studies, political theory and sociology. The possibility of remaining neutral when engaged in cultural studies is summarily rejected, as engagement in cultural studies projects predisposes students towards active intervention in areas of cultural struggle (Leitch 1994:280). The primacy of investigations shifts from the search for some 'real reality behind the texts' to agency and social location in various approaches in biblical studies, such as (inter)cultural studies, autobiographical analysis and different foci on the ethics of interpretation. The context of biblical interpreters and the communities they belong to are no longer of passing interest, if at all, but are in fact increasingly included in academic arguments. ${ }^{31}$ But such developments are not uncomplicated. While for some scholars social identity quests may appear at best useless and at worst 'just one more vain search for the solace of origins, perpetually contested and itself the source of injustice' (Brett 1998:307n15, quoting Furrow), in other parts of the world identity concerns are vital for reasons of self-esteem, sense of self and claiming agency. While theoretically attractive, such sentiments also fail to address the concerns of Two-Thirds of World people who have been deprived of identity and agency in the past and where the lingering consequences of past practices still lead to difficulties in assuming agency even in postcolonial contexts.

However, autobiographical criticism becomes inauthentic when in an extreme postmodernist format it becomes individualistic and self-referring, 'leaving the individual self as an isolated topography of cultural fragments, cobbled together into an incoherent narrative'. The focus on individuals then, ironically, replaces the old, exclusive concern of the author with a new, exclusive concern for the

\footnotetext{
29.Queer theory's particular value is related to two important approaches, which again are related to its own development and subsequent procedures. Firstly, the socially constructed nature of gender and sex in society generally is taken as the socially constructed nature of gender and sex in society generally is taken as the
point of departure rather than assuming a biological or physiological approach. In point of departure rather than assuming a biological or physiological approach. In
short, gender and sex are 'queered' through the exposure of the (powerful) short, gender and sex are 'queered' through the exposure of the (powerful)
systems and structures of convention which require, define and prescribe the form systems and structures of convention which require, define and prescribe the form second aspect of queer theory is often referred to as 'queerying'; it comprises taking social constructionism in sex and gender a step further. Queerying relates to the theoretical and political accommodation of the role of social dynamics and power play in matters of sex and gender, identifying those that benefit from sex and gender constructions and their particular gains.
}

30. Regarding gender and sexuality, the 'affective turn' also holds great promise. It refers to investigations of spheres of experience that focus on the body and not only the mind (and feelings and emotions) beyond the conventional frameworks of representation. For a genealogical tracing of developments of the affective turn, see Clough (2007:1-33).

31.Unfortunately this often amounts to little more than putting across a specific perspective, point of departure or institutional affiliation. 
reader. ${ }^{32}$ '[N]aive or self-serving assertions of unconditioned knowledge have been replaced by self-consciousness concerning the perspectival and value-laden character of claims to knowledge and of all such claims as forms of advocacy' (Davaney 2001:10). Responsible autobiographical concern moves away from the self-absorbed towards accountability for social location, cultural practice and the materialism of biblical interpretation.

\section{Institution and ideology}

Acceptance of the inevitable subjective, autobiographical nature of NT studies does not avert attention from institutional and ideological concerns. ${ }^{33}$ The focus of investigation cannot be trained on either the institutional or the ideological component, since whether the vantage point of study is culturalist or structuralist in orientation, the interplay between institution and ideology in culture remains important. Institutional analysis concentrates on the material 'means and methods' put into practice by institutions participating in the production and circulation of cultural texts and practices. Ideological analysis, on the other hand, accentuates the ideas, emotions and representations embraced and propagated by the products and practices of culture. There is considerable overlap between institutional and ideological analysis (Leitch 1994:280), since the reciprocal relationship between institution and ideology requires at least attention to be given to both aspects, even when one particular orientation is the focus of study. The products, practices and institutions of culture not only create and convey ideology; ideology also gives rise to the formation or moulding of certain products, practices and institutions. In cultural studies, therefore, institutional realignments of traditional subject-matters and research approaches are nothing strange. Accounting for the role of society and culture in NT studies implies also that not only materiality but also conceptuality deserves further attention.

Cultural studies incorporates a distinct resistance element often referred to as a 'leftist political orientation', expressing criticism of aestheticism, formalism, anti-historicism and apoliticism. The traditional, conservative role of the intellectual as connoisseur and custodian of culture is regarded with great suspicion, if not rejected out of hand: '[T] he twin habits of isolating and of monumentalizing the arts and humanities are anathema to adherents of cultural studies' (Leitch 1994:280). Therefore, the presence of resistance and advocacy in cultural studies is not surprising. Then again, the perils accompanying the popularisation and acceptability of bias in academic research are still to be fully explored.

\section{Conclusion}

This contribution is a brief attempt to show how the cultural turn has become evident in various biblical hermeneutical

32.Very few attempts at the autobiographical approach that is reflective-critical endeavour are successful; see Kitzinger (2002) and Staley (1995) as two valuable endeavour are successful; see Kitzinger
contributions; cf Cosgrove et al. (2005).

33.So, too, besides probing the assigning of value to (certain) cultures and laying the politics of representation, for Smith (2014) cultural studies is also about pursuing 'self-reflexive inquiry' and encouraging 'radical progressive cultural politics'. approaches, not an attempt to prescribe cultural studies as the new norm. Nor is it intended simply to replace the existing dominance of historical criticism which is under fire from various directions with another hermeneutical hegemony. The list of cultural studies developments in biblical scholarship is much longer, of course, but the four instances mentioned above signal some of the possibilities offered as well as correctives suggested in such work. At the same time, cultural studies, like any academic pursuit, carries with it potential pitfalls. One danger associated with a cultural turn is the balkanisation of knowledge, especially when traditional scholars withdraw to their 'bounded communities' away from the public realm, or when more liberal scholars engage in uncritical celebration of popular culture, or simply when social location and identity replace reason-giving as the source of legitimation and delegitimation for our positions (Davaney 2001:10)..$^{34}$

Since 'popular culture has emerged no longer as that to be disdained or overcome but as the domain of creative cultural contestation and construction' (Davaney 2001:6), how does it have an impact on biblical studies? Amid the centrality of texts and their attendant contexts it is now the increased focus on their social and the cultural conditions of production as much as their long and convoluted histories of transmission and reception that is central in cultural biblical studies. Obviously the cultural turn does not imply that all readings will be seen as acceptable or useful, but that the importance of the impact of social location on texts is being increasingly acknowledged and interacted with. The cultural turn, though, does imply moving from exclusively theological questions to social history in NT studies. ${ }^{35}$ As Harrill (2011:286) argues for Pauline studies, '[A]n emphasis on the social context of writing and meaning has redrawn the cultural map of Paul's world by rejecting the old "biblical theology" approach': with cultural studies, biblical studies in general embarks on exciting if sometimes unsettling new journeys.

\section{Acknowledgements}

This contribution is offered in honour of Graham Duncan's contribution to religion and theology studies, for the friendship and academic cooperation that started as colleagues at the University of Fort Hare in the nineties, and in appreciation of Graham's scholarship, academic dedication and wholesome human character.

\section{Competing interests}

The author declares that he has no financial or personal relationships which may have inappropriately influenced him in writing this article.

34.Another danger is obscure language. Andrew Louth (2007:215) laments that " $\mathrm{t}$ ] 00 often, however, the cultural turn seems to involve a linguistic turn rather different from that discussed by Liz Clark, namely a turn towards a gestural use of language that seems designed to cloak any meaning with wispy veils of unclarity'.

35.The effect of the cultural turn for theology, Davaney claims (2001:12-13), is twofold: the rejection of the study of religions as sui generis, and with it taking its place as one dimension of human culture; secondly, a strong argument now exists for including theology as an integral part of the study of religion. 


\section{References}

Althaus-Reid, M., 2002, 'The Bible, the empire and the other (review article)', Religion \& Theology 9(5), 398-402. http://dx.doi.org/10.1111/1467-9418.00158

Bhabha, H.K., 1994, The location of culture, Routledge, London.

Blount, B.K., 1995, Cultural interpretation: Reorientating New Testament criticism, Fortress, Minneapolis, MN.

Boas, F., 1887, 'Museums of ethnology and their classification', Science 9(228), 587589. http://dx.doi.org/10.1126/science.ns-9.228.587-a

Bonnell, V.E. \& Hunt, L., 1999, 'Introduction', in V.E. Bonnell \& L. Hunt (eds.), Beyond the Cultural Turn: New directions in the study of society and culture, pp. 1-32, University of California Press, Berkeley, CA.

Brenner, A., 2000, 'Foreword', in G Aichele (ed.), Culture, entertainment and the Bible JSTOT 309, pp. 7-12, Sheffield Academic Press, Sheffield.

Brett, M.G., 1998, 'Locating readers: A response to Frank Moloney', Pacifica 11(3), 303-315.

Brown, D., 2001, 'Refashioning self and other. Theology, academy, and the new ethnography', in D. Brown, S.G. Davaney \& K. Tanner (eds.), Converging on ethnography', in D. Brown, S.G. Davaney \& K. Tanner (eds.), Converging on
culture. Theologians in dialogue with cultural analysis and Criticism, AAR Reflection and Theory in the Study of Religion Series, pp. 41-55, Oxford University Reflection and
Press, Oxford.

Carroll, R.P., 1998, 'Poststructuralist approaches. New historicism and postmodernism', in I Barton (ed.), The Cambridge companion to Biblical interpretation, Cambridge Companions to Religion, pp. 50-66, Cambridge University Press, Cambridge.

Chaney, D., 1994, The cultural turn. Scene-setting essays on contemporary cultural history, Routledge, London.

Clough, P., 2007, 'Introduction', in P. Clough (ed.), The affective turn: Theorizing the social, pp. 1-33, Duke University Press, Durham, NC.

Cosgrove, C.H., Weiss, H. \& Yeo, K., 2005, Cross-cultural Paul. Journeys to others, journeys to ourselves, Eerdmans, Grand Rapids, MI.

Davaney, S.G., 2001, 'Theology and the turn to cultural analysis', in D. Brown, S.G. Davaney \& K. Tanner (eds.), Converging on culture. Theologians in dialogue with cultural analysis and criticism, AAR Reflection and Theory in the Study of Religion Series, pp. 3-16, Oxford University Press, Oxford.

During, S., 2005, Cultural studies: A critical introduction, Routledge, Abingdon.

Easthope, A., 1994, 'Cultural studies. 1. United Kingdom', in M. Groden \& M. Kreiswirth (eds.), The Johns Hopkins guide to literary theory \& criticism, pp. 176-179, Johns Hopkins University Press Baltimore, MD.

Eley, G., 1996, 'Is all the world a text? From social history to the history of society two decades later', in T.J. McDonald (ed.), The historic turn in the human sciences, pp. 193-243, University of Michigan Press, Ann Arbor, MI.

Exum, J.C. \& Moore, S.D., (eds.), 1998. Biblical studies/cultural studies. The Third Sheffield Colloquium. Gender, culture, theory, vol 7. Sheffield Academic Press, Sheffield.

Frye, N., 1982, The Great Code: The Bible and literature, Ark Paperbacks, London.

Gallagher, S.V., 1996, 'Mapping the hybrid world: Three postcolonial motifs', Semeia $75,229-240$

Geertz, C., 1973, The interpretation of cultures: Selected essays, Basic Books, San Francisco, CA

Glancy, J.A., 1998, 'House readings and field readings: The discourse of slavery and biblical/cultural studies', in J.C. Exum \& S.D. Moore (eds.), Biblical studies/cultura studies. The Third Sheffield Colloquium, gender, culture, theory, pp. 460-477, Sheffield Academic Press, Sheffield.

Goss, J., 1996, 'Postcolonialism: Subverting whose empire?', Third World Quarterly 17(2), 239-250. http://dx.doi.org/10.1080/01436599650035662

Harrill, J.A., 2011, 'Paul and empire: Studying Roman identity after the cultural turn', Early Christianity 2(3), 281-311. http://dx.doi.org/10.1628/186870311797406958

Horsley, R.A., 1995, 'Innovation in search of reorientation. New Testament studies rediscovering its subject matter', Journal of the American Academy of Religion 62(4), 1127-1166.

Kwok, P-L., 2005, Postcolonial imagination and feminist theology, WJK, Louisville, KY.

Leitch, V.B., 1994, 'Cultural studies. 2. United States', in M. Groden \& M. Kreiswirth (eds.), The Johns Hopkins guide to literary theory \& criticism, pp. 179-182. John Hopkins University Press, Baltimore, MD.

Lopez, D., 2011, 'Visualizing significant otherness. Reimagining Paul (ine studies) through hybrid lenses', in C.D. Stanley (ed.), The Colonized Apostle. Paul through Postcolonial Eyes, Paul in Critical Contexts, pp. 74-94, Fortress, Minneapolis, MN.

Louth, A., 2007, 'Review', Theology \& Sexuality 13(2), 214-215. http://dx.doi.org/ $10.1177 / 1355835806074438$
Martin, D.B., 2005, 'Introduction', in D.B. Martin, \& P.C. Miller (eds.), The cultural turn in late ancient studies, gender, asceticism, and historiography, pp, 1-21, Duke University Press. Durham.
Un

Miller, T., 2001, 'What it is and what is isn't. Introducing ... cultural studies', in T. Miller (ed.), A companion to cultural studies, pp. 1-19, Blackwell, Malden, MA.

Moore, S.D., (ed.), 1998, Semeia 82. In search of the present: The Bible through cultural studies. SBL, Atlanta, GA.

Port, A.I., 2015, 'History from below, the history of everyday life, and microhistory', in J.D. Wright (ed.), International encyclopedia of the social \& behavioral sciences, 2nd edn., pp. 108-113, Elsevier, New York.

Punt, J., 2011, 'Queer theory, postcolonial theory, and biblical interpretation. A preliminary exploration of some intersections', in T.J. Hornsby \& K. Stone (eds.), Bible trouble: Queer reading at the boundaries of Biblical scholarship, Semeia Studies, pp. 321-341,Vol. 67, SBL, Atlanta, GA.

Punt, J., 2012, 'Dealing (with) the past and future of biblical studies. A new South African perspective', in R. Boer \& F.F. Segovia (eds.), The future of the Biblical Past:
Envisioning Biblical studies on a global key, Semeia Studies, vol 66, pp. 29-45. SBL, Envisioning
Atlanta, GA

Richard, R. (ed.), 1967, The linguistic turn: Recent essays in philosophical method, University of Chicago Press, Chicago, IL.

Rowland, C. 1993, 'Open thy mouth for the dumb'. A task for the exegete of Holy Scripture', Biblical Interpretation 1(2), 228-245. http://dx.doi.org/10.1163/ $156851593 \times 00070$

Rushdie, S., 1991, Imaginary homelands: Essays and criticism 1981-1991, Granta, London.

Schüssler Fiorenza, E., 1999, Rhetoric and ethic. The politics of Biblical studies, Fortress, Minneapolis, MN.

Segovia, F.F., 1995a, 'Towards a hermeneutics of the diaspora: A hermeneutics of otherness and engagement', in F.F. Segovia \& M.A. Tolbert (eds.), Reading from this place. I. Social location and Biblical interpretation in the United States, pp. 57-73. Fortress, Minneapolis, MN.

Segovia, F.F., 1995b, 'Towards intercultural criticism: A reading strategy from the diaspora', in F.F. Segovia \& M.A. Tolbert (eds.), Reading from this place. II. Socia

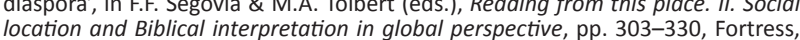
location and Biblical
Minneapolis, MN.

Segovia, F.F., 1995c, 'The text as other: Towards a Hispanic American hermeneutic', in D Smith-Christopher (ed.), Text \& experience. Towards a cultural exegesis of the Bible, Biblical Seminar, pp. 276-298, Sheffield Academic Press, Sheffield.

Segovia, F.F., 2000, Decolonizing Biblical Studies. A view from the margins, Orbis, Maryknoll.

Smith, A., 2013, 's v cultural studies', in S.L. McKenzie (ed.), Oxford encyclopedia of Biblical interpretation, Oxford University Press, London.

Smith, A. 2014. Cultural Studies. In S. McKenzie (ed.), Oxford Encyclopedia of Biblical Interpretation. Oxford Biblical Studies Online, http://www.oxfordbiblicalcstudies. com/article/opr/t373/e58 (accessed May 10, 2016)

Staley, J.L., 1995, Reading with a passion. Rhetoric, autobiography, and the American West in the Gospel of John, Continuum, New York.

Stanley, C.D., 2011, 'Paul the ethnic hybrid? Postcolonial perspectives on Paul's ethnic categorizations', in C.D. Stanley (ed.), The Colonized Apostle. Paul through postcolonial eyes, Paul in critical contexts, pp. 110-126, Fortress, Minneapolis, MN.

Sugirtharajah, R.S., 2002, Postcolonial criticism and Biblical interpretation, Oxford University Press, Oxford.

Sugirtharajah, R.S., 2003, Postcolonial reconfigurations. An alternative way of reading the Bible and doing theology, SCM, London.

Tanner, K., 2001, 'The religious significance of Christian engagement in the culture wars', Theology Today 58(1), 28-43. http://dx.doi.org/10.1177/004057360105800105

Theissen, G., 2007, The Bible and contemporary culture, trans. D.E Green, Originally published as Zur Bibel motivieren: Aufgaben, Inhalte, und Methoden einen offenen Bibeldidaktik. 2002. Fortress, Minneapolis, MN.

Tracy, D., 1981, The analogical imagination: Christian theology and the culture of pluralism, Crossroad, New York.

Tracy, D., 1987, Plurality and ambiguity: Hermeneutics, religion, hope. Harper \& Row, San Francisco, CA.

Vanhoozer, K.J., Anderson, C.A. \& Sleasman, M.J. (eds.), 2007, Everyday theology. how to read cultural texts and interpret trends, Cultural Exegesis. Baker Academic, Grand Rapids, MI.

Williams, R., 1983, 's v culture', in R Williams (rev ed.), Keywords. A vocabulary of culture and society, pp. 87-93, Oxford University Press, New York.

Wimbush, V.L., 1993, 'Reading texts through worlds, worlds through texts', Semeia 62, 129-139. 